\title{
The region ahead of the pancreas is a suitable place for performing endoscopic ultrasound-guided gastroenterostomy: from clinical data to swine trial
}

\section{Technical advance}

Keywords:

Posted Date: October 26th, 2020

DOl: https://doi.org/10.21203/rs.3.rs-30319/v2

License: (c) (i) This work is licensed under a Creative Commons Attribution 4.0 International License. Read Full License 


\section{Abstract}

The authors have requested that this preprint be withdrawn due to erroneous posting.

\section{Full Text}

The authors have withdrawn this preprint from Research Square. 